\title{
ESTIMATION OF FLUORINE AND SULFUR BEHAVIORS AFFECTED BY CONVERTER OFF-GAS DUSTS
}

\author{
Sen Li and Xiaolin Wei \\ Institute of Mechanics, Chinese Academy of Sciences, Beijing, China
}

Converter steelmaking produces a large amount of high-temperature flue, which contains pollutant gases $\left(\mathrm{SO}_{2}, \mathrm{HF}\right.$, etc.) and entrains fine dusts $\left(\mathrm{Fe}, \mathrm{FeO}, \mathrm{Fe}_{2} \mathrm{O}_{3}, \mathrm{CaO}\right.$, etc.), and fluorine and sulfur behaviors that were affected by dusts in off-gas are estimated by chemical equilibrium method. The behaviors of fluorine and sulfur in off-gas are very different at reducing and oxidizing atmospheres. At a reducing atmosphere, main fluorides in off-gas are $\mathrm{SiF}_{4}(\mathrm{~g}), \mathrm{CaF}_{2}(\mathrm{~s}), \mathrm{HF}$, and $\mathrm{CaF}_{2}(\mathrm{~g})$; the main sulfides are $\mathrm{FeS}_{2}(\mathrm{~s}), \mathrm{FeS}(\mathrm{s})$, $\mathrm{COS}(\mathrm{g}), \mathrm{SO}_{2}(\mathrm{~g})$, and $\mathrm{S}_{2}(\mathrm{~g})$; and $\mathrm{CaO}$ can effectively defluorine at $\mathrm{T}<1000 \mathrm{~K}$. At oxidizing atmosphere, main fluorides are $\mathrm{SiF}_{4}(\mathrm{~g}), \mathrm{HF}$, and $\mathrm{CaF}_{2}(\mathrm{~g})$; the main sulfides are $\mathrm{Fe}_{2}\left(\mathrm{SO}_{4}\right)_{3}(\mathrm{~s}), \mathrm{CaSO}_{4}(\mathrm{~s}), \mathrm{SO}_{2}(\mathrm{~g})$, and $\mathrm{SO}_{3}(\mathrm{~g})$; and defluorination and desulfurization by dusts are completely effectively at $M R \geq 1$ and $T<1100 \mathrm{~K}$.

Keywords: Converter off-gas; Dust; $\mathrm{HF} ; \mathrm{SO}_{2}$

\section{INTRODUCTION}

A large amount of high-temperature flue is formed during converter steelmaking, which is the major steelmaking method (Aleksashin et al., 2007; Feng, 2005), and the flue is called converter off-gas, which contains $\mathrm{CO}, \mathrm{CO}_{2}$, and pollutant gases $\left(\mathrm{SO}_{2}, \mathrm{NO}_{x}, \mathrm{HF}\right.$, etc.) and entrains a large amount of fine dusts ( $\mathrm{Fe}, \mathrm{FeO}, \mathrm{Fe}_{2} \mathrm{O}_{3}$, $\mathrm{CaO}, \mathrm{MgO}, \mathrm{MnO}, \mathrm{SiO}_{2}$, etc.). During converter steelmaking, $\mathrm{CO}$ and $\mathrm{CO}_{2}$ in off-gas are formed from decarburization reaction in steel bath, pollutant gases $\left(\mathrm{SO}_{2}\right.$ and $\mathrm{HF})$ in off-gas are formed from metal materials $\left(\mathrm{FeS}_{2}\right)$ and flux materials $\left(\mathrm{CaF}_{2}\right)$, and $\mathrm{SO}_{2}$ and $\mathrm{HF}$ can reach 5-20 ppm and 35-200 ppm, respectively. The maximum content of $\mathrm{CO}$ in the converter off-gas can reach $80 \%$ at an average content of about $60 \%$, and the temperature can reach $1700 \mathrm{~K}$. The amount of the dusts entrained by off-gas is about $80-150 \mathrm{~g} / \mathrm{m}^{3}$, and the typical chemical composition of dust contained in converter gas is $72.0 \% \mathrm{Fe}_{2} \mathrm{O}_{3}, 0.80 \% \mathrm{SiO}_{2}, 9.04 \% \mathrm{CaO}$, etc. (Feng, 2005).

$\mathrm{SO}_{2}$ is a known precursor to formation of ozone and acid rain. Hydrogen fluoride (HF) can damage human health, and an aqueous solution of $\mathrm{HF}$ is strongly corrosive. $\mathrm{CaO}, \mathrm{Fe}$, and $\mathrm{Fe}_{2} \mathrm{O}_{3}$ are good desulfurization and defluorination agents during coal combustion, and $\mathrm{SiO}_{2}$ has a great influence on desulfurization (Cheng et al., 2003; Qi et al., 2008a). CaO is also considered as an effective sorbent for

Received 18 August 2010; revised 18 February 2011; accepted 22 February 2011.

Address correspondence to Sen Li, Institute of Mechanics, Chinese Academy of Sciences, No. 15 Beisihuanxi Road, Beijing 100190, China. E-mail: lisen@imech.ac.cn 
$\mathrm{HF}$, and Dehne (1987) verified that $\mathrm{HF}$ would react with $\mathrm{CaCO}_{3}$ and $\mathrm{CaO}$ in soil and might result in the decrease of fluoride emission during the firing of ceramic products (Xie et al., 2003). Metallurgical dusts (MD) have strong abilities to absorb sulfides, and they are used as sulfur absorbents in the FGD process (Guo et al., 1999; Ye et al., 2000; Zhao et al., 2004).

The steelmaking industry must carry out the ecological and sustainable development to control gaseous pollutants ( $\mathrm{SO}_{2}, \mathrm{HF}$, and other emissions). In order to reduce gaseous pollutant emissions of converter off-gas, effective use of the desulfurization and defluorination of dusts $\left(\mathrm{CaO}, \mathrm{Fe}, \mathrm{Fe}_{2} \mathrm{O}_{3}, \mathrm{SiO}_{2}\right.$, etc. $)$ is very necessary and important. In the practical steelmaking process, converter off-gas discharge is intermittent, its composition concentration and temperature frequently vary, and the off-gas dust may become the ignition source during off-gas cooling, and then there is potential explosion danger. At present, in order to prevent off-gas explosion and ensure safety, dust precipitation and off-gas quenching are carried out by spraying a large amount of water into the high-temperature off-gas, as dusts cannot play a role in the desulfurization and defluorination of off-gas, and this wastes a large amount of water and heat and causes secondary water pollution. With the technology development of explosion protection, the dust precipitation and off-gas quenching by spraying water can be cancelled, the sensible and chemical heats of high-temperature converter off-gas can be effectively recovered, and the desulfurization and defluorination of off-gas can be carried by dusts.

At present, the study on desulfurization and defluorination of converter off-gas by dusts is rare, and the temperature and atmosphere of converter off-gas have influences on desulfurization and defluorination. In this article, the behaviors of fluorine and sulfur are estimation using the NASA-Glenn CEA2 (Chemical Equilibrium and Applications 2) equilibrium code (McBride et al., 2002), and the influences of temperature and atmosphere of converter off-gas on desulfurization and defluorination are investigated.

\section{CALCULATION METHOD}

The Chemical Equilibrium for Applications (CEA), developed at NASA's Glenn Research Center, is a program that calculates chemical equilibrium product concentrations from any set of reactants and determines thermodynamic and transport properties for the product mixture (McBride, 2002; Sanford and Bonnie, 1994). Although this type of equilibrium calculation assumes that the residence time of the reactants is infinite, CEA code calculates mixture properties and equilibrium concentrations for a wide variety of applications, and the ability to calculate chemical equilibrium is a useful approximation for many engineering applications (Alfonso and Sung, 2006; Mjaanes et al., 2005; Vican et al., 2002). For combustion processes, it represents complete chemical reaction and the conversion of all available fuel to energy. The CEA version 2.0 code is called SUBEQ, and it is a callable subroutine that can be used within a calling program to calculate mixture properties and equilibrium concentrations for a wide variety of applications.

CEA code was employed to predict equilibrium compositions by conventional thermodynamic calculations based on the minimization of the free Gibbs energy, and it does not take kinetic phenomena into account. A closed system under constant 
temperature and pressure is adopted, it is assumed that all gases are ideal and that interactions among phases may be neglected, and stable solids are considered as condensed phase which are pure. Any condensed species are assumed to occupy a negligible volume relative to the gaseous species, and this is assumed to be correct even when small amounts of condensed species (up to several percent by weight) are present. The diffusion of the gas species to dust surfaces and the dust size are not considered in the CEA code. The default library provides property values for temperatures up to $6000 \mathrm{~K}$ for all data in the CEA database, and 258 species are involved in the equilibrium calculation.

$\mathrm{CaO}$ is an effective sorbent for $\mathrm{SO}_{2}$ and $\mathrm{HF}$ sorbent, and its abilities to desulfurize and defluorinate are influenced by temperature and the composition of flue gas. The desulfurization and defluorination products are $\mathrm{CaSO}_{4}(\mathrm{~s}) / \mathrm{CaS}(\mathrm{s})$ and $\mathrm{CaF}_{2}(\mathrm{~s})$. In order to investigate the influence of $\mathrm{CaO}$ content in dusts on desulfurization and defluorination, the relative mole content of calcium is defined as $(M R)$ :

$$
M R=\frac{M_{\mathrm{CaO}}}{M_{\mathrm{HF}} / 2+M_{\mathrm{SO}_{2}}}
$$

where $M_{\mathrm{CaO}}, M_{\mathrm{HF}}$, and $M_{\mathrm{SO}_{2}}$ are the mole numbers of $\mathrm{CaO}, \mathrm{HF}$, and $\mathrm{SO}_{2}$, respectively. $M R$ also can be expressed as

$$
M R=\frac{1}{1 /\left(2 R_{\mathrm{Ca} / \mathrm{F}}\right)+1 / R_{\mathrm{Ca} / \mathrm{S}}}
$$

where $R_{\mathrm{Ca} / \mathrm{F}}$ is the molar ratio of calcium to fluorine and $R_{\mathrm{Ca} / \mathrm{S}}$ is the molar ratio of calcium to sulfur.

\section{RESULTS AND DISCUSSIONS}

In the chemical equilibrium calculation, the compositions of converter off-gas are $65 \% \mathrm{CO}, 0.1 \% \mathrm{H}_{2} \mathrm{O}, 25 \mathrm{ppm} \mathrm{HF}, 150 \mathrm{ppm} \mathrm{SO}_{2}$, and the residual gas $\mathrm{CO}_{2}$. The dust content is $120 \mathrm{~g} / \mathrm{m}^{3}$ in converter off-gas.

\section{The Influence of Air Stoichiometric Ratio on the Behaviors of Fluorine and Sulfur During Off-Gas Combustion}

Air stoichiometric ratio [SR, (actual air supplied)/(stoichiometric air demand of fuel)] influences combustion atmosphere. Converter off-gas contains highconcentration $\mathrm{CO}$, and the off-gas is often recovered or partially combusted in the cooling stack at $S R<1$ where the combustion atmosphere of off-gas is reducing. In order to utilize the energy of off-gas, off-gas can be completely combusted to heat water vapor in the cooling stack at $S R>1$ where the combustion atmosphere of off-gas is oxidizing. During off-gas combustion, $\mathrm{HF}$ and $\mathrm{SO}_{2}$ in off-gas occurs in complex chemical reactions with off-gas dusts in the cooling stack.

In the chemical equilibrium calculation, the compositions of dust are $0.58 \% \mathrm{Fe}$, $72.00 \% \mathrm{Fe}_{2} \mathrm{O}_{3}, 0.80 \% \mathrm{SiO}_{2}$, and $9.04 \% \mathrm{CaO}$. The equilibrium calculation results of fluorine and sulfur in off-gas indicate that the influence of $S R$ on the distribution 


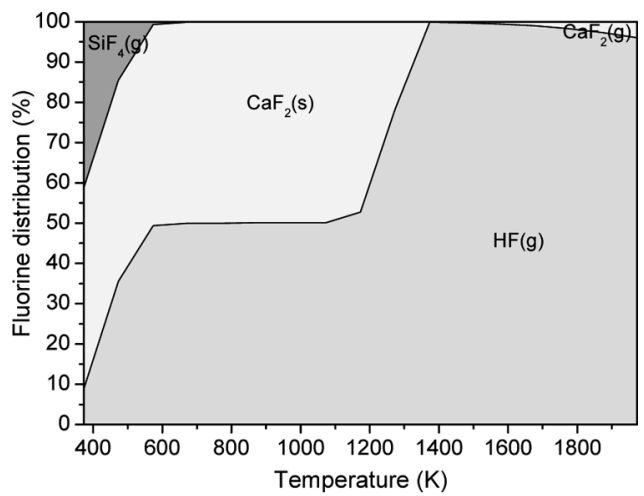

(a)

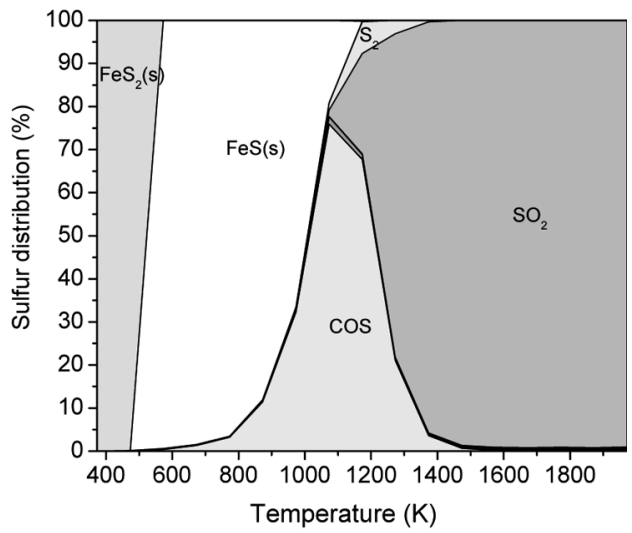

(b)

Figure 1 The equilibrium distributions of fluorine and sulfur in off gas at $S R=0.8$.

of fluorine/sulfur is negligible when $S R$ is less than 1 at a given dust composition. Here, the distributions of fluorine and sulfur are only presented at $S R=0.8$, as shown in Figure 1. In the temperature range of 373-1973 K, the main fluorides are $\mathrm{SiF}_{4}(\mathrm{~g})(\mathrm{T}<600 \mathrm{~K}), \mathrm{CaF}_{2}(\mathrm{~s})(\mathrm{T}<1300 \mathrm{~K}), \mathrm{HF}$, and $\mathrm{CaF}_{2}(\mathrm{~g})(\mathrm{T}>1600 \mathrm{~K})$, and the main sulfides are $\mathrm{FeS}_{2}(\mathrm{~s}) \quad(\mathrm{T}<600 \mathrm{~K}), \quad \mathrm{FeS}(\mathrm{s}) \quad(500<\mathrm{T}<1100 \mathrm{~K}), \quad \mathrm{COS}(\mathrm{g})$ $(600<\mathrm{T}<1500 \mathrm{~K}), \mathrm{SO}_{2}(\mathrm{~g})(\mathrm{T}>1100 \mathrm{~K})$, and $\mathrm{S}_{2}(\mathrm{~g})$. The equilibrium calculation results of fluorine and sulfur in off-gas indicate that the influence of the air stoichiometric ratio on the distribution of fluorine/sulfur is also negligible when $S R$ is larger than 1 at a given dust composition. Here, the distributions of fluorine and sulfur are only presented at $S R=1.1$, as shown in Figure 2. In the temperature range of $373-1973 \mathrm{~K}$, the main fluorides are $\mathrm{SiF}_{4}(\mathrm{~g})(\mathrm{T}<600 \mathrm{~K}), \mathrm{HF}$, and $\mathrm{CaF}_{2}(\mathrm{~g})$ $(\mathrm{T}>1600 \mathrm{~K})$, and the main sulfides are $\mathrm{Fe}_{2}\left(\mathrm{SO}_{4}\right)_{3}(\mathrm{~s})(\mathrm{T}<500 \mathrm{~K}), \mathrm{CaSO}_{4}(\mathrm{~s})$ $(\mathrm{T}<1200 \mathrm{~K}), \mathrm{SO}_{2}(\mathrm{~g})$, and $\mathrm{SO}_{3}(\mathrm{~g})$. The results indicate that the behaviors of fluorine and sulfur during off-gas combustion are very different at reducing and oxidizing atmospheres. The detailed behaviors of fluorine and sulfur are discussed in the following sections. 


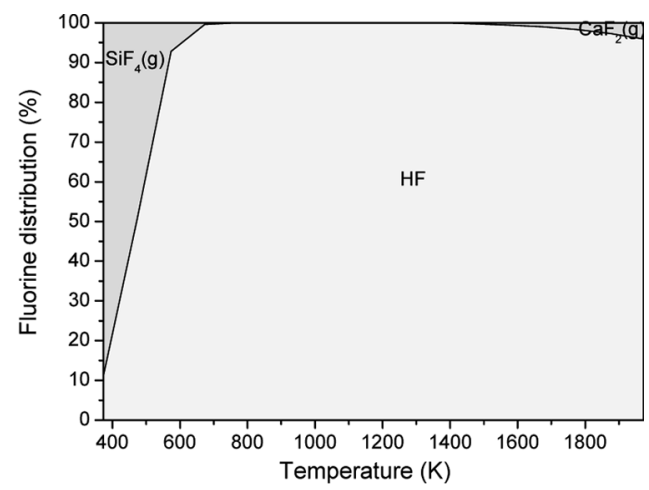

(a)

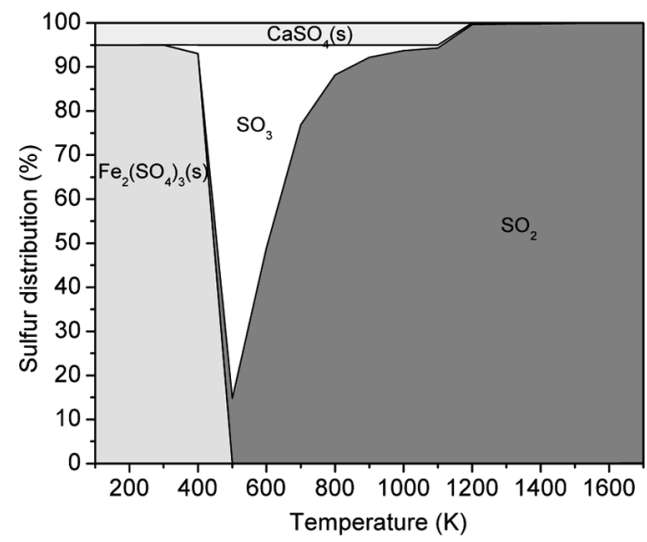

(b)

Figure 2 The equilibrium distributions of fluorine and sulfur in off gas at $S R=1.1$.

\section{The Behaviors of Fluorine and Sulfur in Converter Off-Gas Under Reducing Atmosphere}

The behavior of fluorine in converter off-gas under reducing atmosphere. Figure 3 shows the equilibrium calculation results of fluorine in off-gas at reducing atmosphere, and the results indicate that the distributions of fluoride at reducing atmosphere are very similar at $M R \geq 0.0909$, and main species containing fluorine are $\mathrm{HF}(\mathrm{g}), \mathrm{SiF}_{4}(\mathrm{~g}), \mathrm{CaF}_{2}(\mathrm{~s})$, and $\mathrm{CaF}_{2}(\mathrm{~g})$. As can be seen in Figure 3, the behaviors of fluorine in off-gas indicate that the defluorination product is $\mathrm{CaF}_{2}(\mathrm{~s})$ at $\mathrm{T}<1400 \mathrm{~K}$, which indicates that $\mathrm{CaO}$ is an effective sorbent for $\mathrm{HF}$. At $\mathrm{T}>1400 \mathrm{~K}$, the main fluoride is $\mathrm{HF}$; at $M R=0.0455$, the mole ratio of $\mathrm{CaO}$ to $\mathrm{HF}$ is 0.25 ; $\mathrm{CaO}$ is not enough to defluorinate at $\mathrm{T}<1400 \mathrm{~K}$; and then $\mathrm{HF}$ reacts with $\mathrm{SiO}_{2}$ to form gaseous $\mathrm{SiF}_{4}$ at $\mathrm{T}<600 \mathrm{~K}$. The fluorine retention reaction of $\mathrm{CaO}$ is

$$
\mathrm{CaO}(\mathrm{s})+2 \mathrm{HF}(\mathrm{g}) \rightleftharpoons \mathrm{CaF}_{2}(\mathrm{~s})+\mathrm{H}_{2} \mathrm{O}(\mathrm{g})
$$




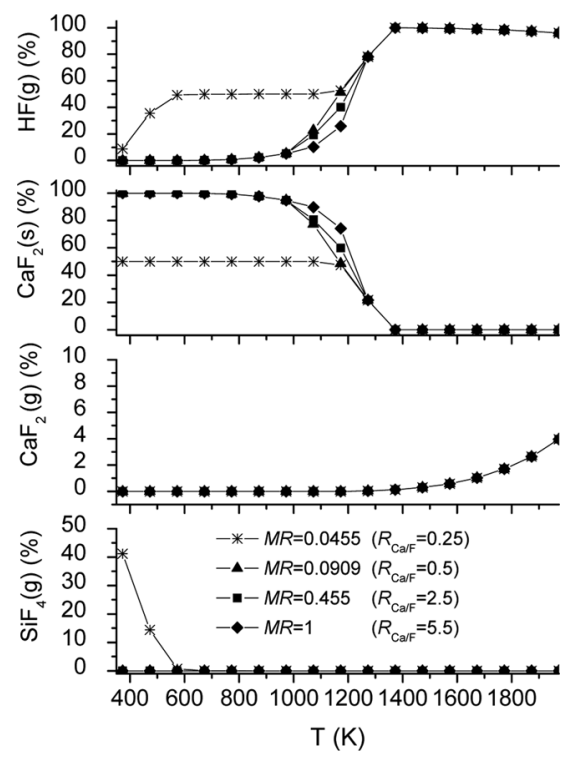

Figure 3 The equilibrium calculation results of fluorine in off-gas at reducing atmosphere $(S R=0.8)$.

Since $\mathrm{CaO}$ in off-gas dusts is the only sorbent for $\mathrm{HF}, \mathrm{CaO}$ content is crucial to defluorination. As can be seen in Figure 3, at $\mathrm{T}>1100 \mathrm{~K}$, HF releases rapidly with the increase of temperature, which means that rising temperature is unfavorable for fluorine to undergo retention reaction (forward reaction). Experiments of the clay brick process demonstrated that $\mathrm{HF}$ releases at $\mathrm{T}>1100 \mathrm{~K}$, and the defluorination sorbent, $\mathrm{CaO}$, is ineffective for defluorination at $\mathrm{T}>1250$ (Gonzalez et al., 2002; $\mathrm{Wu}$ et al., 2001). Studies on high-temperature stability property of analytical pure $\mathrm{CaF}_{2}$ by Byer et al. (1983) and Qi et al. (2002) show that the $\mathrm{CaF}_{2}$ hydrolytic reaction takes place for $\mathrm{CaF}_{2}$ at high temperature. These experiment results are approximate to the equilibrium calculation of fluorine, and thus the equilibrium calculation is effective to analyze the influence of temperature on the defluorination of converter off-gas dusts.

The main reason that the calcium-based sorbent fluorine retention effects reduce under the conditions of high temperature is that the fluorine retention product decomposition action at very high temperature is strengthened (Qi et al., 2008b). The thermodynamic analysis of Equation (3) is useful to investigate the influences of temperature on the fluorine retention. The temperature has the notable action on its reaction balance movement. For the reversible Equation (3), Gibbs energy $\Delta_{\mathrm{r}} G_{\mathrm{m}}^{\Theta}(T)$ and the reaction equilibrium constant $K^{\Theta}(T)$ can be calculated, as shown in Table 1 . The thermodynamic analysis shows that the fluorine retention in Equation (3) is the exothermic reaction. $\Delta_{\mathrm{r}} G_{\mathrm{m}}^{\Theta}(T)$ gradually increases, and $K^{\Theta}(T)$ drastically decreases with rising reaction temperature, and this means that rising temperature is unfavorable to for the fluorine reaction (forward reaction) to proceed. Therefore, from the angle of the thermodynamics, in order to enhance the defluorination rate, the defluorination reaction should be controlled in relative low temperature conditions. 
Table 1 The standard Gibbs energy and equilibrium constant of fluorine retention Equation (3)

\begin{tabular}{lcccccc}
\hline $\mathrm{T}(\mathrm{K})$ & 373 & 473 & 573 & 673 & 773 & 873 \\
$\Delta_{\mathrm{r}} G_{\mathrm{m}}^{\Theta}(T)$ & -240.4 & -227.7 & -215.0 & -202.5 & -190.07 & -177.8 \\
$K^{\Theta}(T)$ & $4.7 \mathrm{E}+33$ & $1.4 \mathrm{E}+25$ & $4.0 \mathrm{E}+19$ & $5.2 \mathrm{E}+15$ & $7.0 \mathrm{E}+12$ & $4.3 \mathrm{E}+10$ \\
$\mathrm{~T}(\mathrm{~K})$ & 973 & 1073 & 1173 & 1273 & 1373 & 1473 \\
$\Delta_{\mathrm{r}} G_{\mathrm{m}}^{\Theta}(T)$ & -165.6 & -153.6 & -141.8 & -130.217 & -119.0 & -108.5 \\
$K^{\Theta}(T)$ & $7.8 \mathrm{E}+8$ & $3.0 \mathrm{E}+7$ & $2.1 \mathrm{E}+6$ & $2.2 \mathrm{E}+5$ & $3.4 \mathrm{E}+4$ & $7.1 \mathrm{E}+3$ \\
\hline
\end{tabular}

As known from Figure 3, at $M R<0.0909$, where the mole ratio of $\mathrm{CaO}$ to $\mathrm{HF}$ is less than 0.5 , the amount of $\mathrm{CaO}$ is not enough to completely defluorinate at $\mathrm{T}<600 \mathrm{~K}$, and the residual $\mathrm{HF}$ can react with $\mathrm{SiO}_{2}$ to form gaseous $\mathrm{SiF}_{4}$.

$$
\mathrm{SiO}_{2}(\mathrm{~s})+4 \mathrm{HF}(\mathrm{g}) \rightleftharpoons \mathrm{SiF}_{4}(\mathrm{~g})+2 \mathrm{H}_{2} \mathrm{O}(\mathrm{g})
$$

$\mathrm{SiF}_{4}$ is a corrosive chemical, it is toxic, and it can severely irritate and burn the skin and eyes. The equilibrium constant of Equation (4) is $1.50 \times 10^{9} \sim 4.28 \times 10^{15}$ at $400<\mathrm{T}<600 \mathrm{~K}$, and the equilibrium constant decreases with the increase of temperature. The equilibrium calculation results of the fluorine behaviors indicate that gaseous $\mathrm{SiF}_{4}$ does not occur at $R_{\mathrm{Ca} / \mathrm{F}} \geq 0.5$ where the amount of $\mathrm{CaO}$ is enough to defluorinate.

As known from Equation (3), $\mathrm{H}_{2} \mathrm{O}$ has promoting effects on the release of $\mathrm{HF}$. When the initial content of moisture increases, it is unfavorable for the forward reaction in fluorine Equation (3) to proceed, and then the release amount of HF increases. During converter off-gas recovery, ambient air inevitably leaks into off-gas through the moveable hood mouth of the steelmaking converter, and $\mathrm{H}_{2} \mathrm{O}$ vapor in the leaking air makes the $\mathrm{H}_{2} \mathrm{O}$ concentration in off-gas is $0.1-0.4 \%$. Figure 4 shows the influences of the moisture content and temperature on the profiles of $\mathrm{CaF}_{2}(\mathrm{~s})$ and $\mathrm{HF}(\mathrm{g})$. The results indicate that $\mathrm{HF}$ rapidly releases when the temperature is higher than $1000 \mathrm{~K}$, and $\mathrm{CaO}$ as sorbent for $\mathrm{HF}$ is completely ineffective at $\mathrm{T}>1500 \mathrm{~K}$.

When the moisture content of the off-gas is larger than $0.4 \%$, the influence of moisture content on the ability of off-gas dust fluorine retention is almost similar. With the increase of temperature at $1000<\mathrm{T}<1500 \mathrm{~K}$, solid $\mathrm{CaF}_{2}$ (s) profiles drastically decreases, and gaseous HF increases, which means that the defluorination reaction should be controlled at $\mathrm{T}<1000 \mathrm{~K}$.

As known from Equation (3), at $\mathrm{T}>1500 \mathrm{~K}$, gaseous $\mathrm{CaF}_{2}$ releases, and its amount increases with the increase of temperature, which leads to the decrease of $\mathrm{HF}$. At high temperature, $\mathrm{CaO}(\mathrm{s})$ begins to vaporize; $\mathrm{CaO}(\mathrm{g})$ easily reacts with $\mathrm{HF}$ to produce $\mathrm{CaF}_{2}(\mathrm{~g})$ and $\mathrm{H}_{2} \mathrm{O}(\mathrm{g})$ [see Equation (5)]; and the increasing temperature makes $\mathrm{H}_{2} \mathrm{O}(\mathrm{g})$ decompose into $\mathrm{H}$ and $\mathrm{OH}$ ions [see Equation (6)] that are rapidly consumed to form $\mathrm{H}_{2}, \mathrm{Fe}(\mathrm{OH})_{2}, \mathrm{Ca}(\mathrm{OH})_{2}$ [see Equations (7)-(9), which are favorable to the undergoing of the fluorine reaction, the forward reaction of Equation (5)]. Therefore, at $\mathrm{T}>1500 \mathrm{~K}$, increasing the temperature causes more gaseous $\mathrm{CaF}_{2}$ to release (see Figure 3).

$$
\mathrm{CaO}(\mathrm{g})+2 \mathrm{HF}(\mathrm{g}) \rightleftharpoons \mathrm{CaF}_{2}(\mathrm{~g})+\mathrm{H}_{2} \mathrm{O}(\mathrm{g})
$$




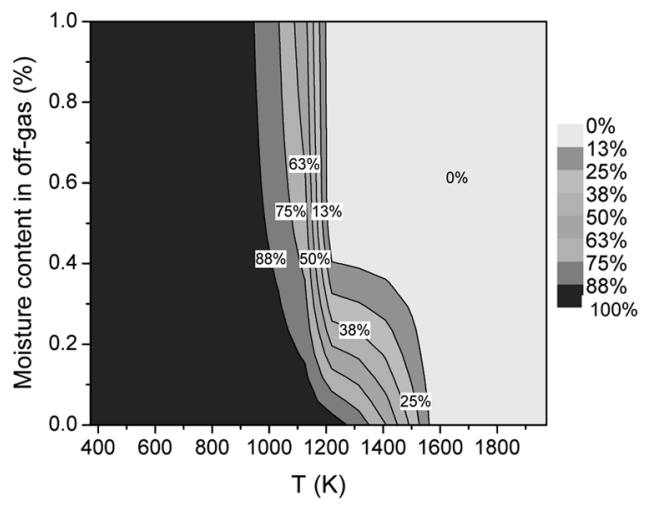

(a) $\mathrm{CaF}_{2}(\mathrm{~s})$ profiles

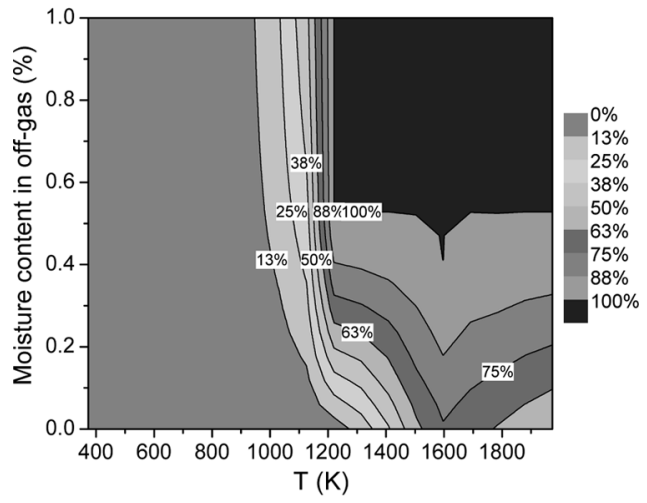

(b) $\mathrm{HF}(\mathrm{g})$ profiles

Figure 4 The profiles of solid $\mathrm{CaF}_{2}$ and gaseous $\mathrm{HF}$ as a function of the initial content of moisture and temperature.

$$
\begin{gathered}
\mathrm{H}_{2} \mathrm{O}(\mathrm{g}) \rightleftharpoons \mathrm{H}+\mathrm{OH} \\
\mathrm{H}+\mathrm{H} \longrightarrow \mathrm{H}_{2} \\
2 \mathrm{OH}+\mathrm{Fe} \longrightarrow \mathrm{Fe}(\mathrm{OH})_{2} \\
2 \mathrm{OH}+\mathrm{Ca} \longrightarrow \mathrm{Ca}(\mathrm{OH})_{2}
\end{gathered}
$$

The reaction paths of the fluorine species are summarized in Figure 5.

The behaviors of sulfur in converting off-gas at reducing atmosphere. Figure 6 illustrates the equilibrium distributions of sulfur in off-gas as a function of temperature at $M R=0.0455$ and 1 . The equilibrium calculation results indicate that sulfur species in off-gas are $\mathrm{FeS}_{2}(\mathrm{~s}), \mathrm{FeS}(\mathrm{s}), \mathrm{CaS}(\mathrm{s}), \mathrm{COS}(\mathrm{g})$, $\mathrm{S}_{2}(\mathrm{~g}), \mathrm{SO}(\mathrm{g})$, and $\mathrm{SO}_{2}(\mathrm{~g})$ at reducing atmosphere, and the main sulfur-containing species are $\mathrm{FeS}_{2}(\mathrm{~s})$ at $\mathrm{T}<473 \mathrm{~K}, \mathrm{FeS}(\mathrm{s})$ at $473<\mathrm{T}<1000 \mathrm{~K}$, and $\mathrm{CaS}(\mathrm{s})$ at $1000<\mathrm{T}<1400 \mathrm{~K}$. Figure 7 shows the influences of $M R$ and temperature on the 


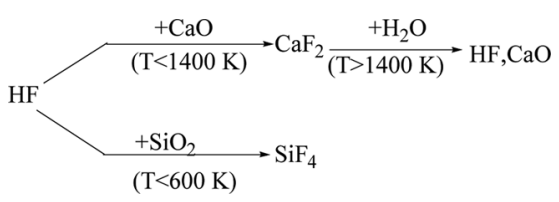

Figure 5 The reaction paths of fluorine species.

main sulfur species in off-gas at reducing atmosphere, and the results indicate $M R$ and $\mathrm{R}_{\mathrm{Ca} / \mathrm{S}}$ have little effects on the distribution of $\mathrm{FeS}_{2}(\mathrm{~s}), \mathrm{FeS}(\mathrm{s})$, and $\mathrm{SO}_{2}(\mathrm{~g})$, and $\mathrm{CaS}$ increases with $M R$.

At reducing atmosphere, the desulfurization reactions must be considered:

$$
\mathrm{Fe}_{2} \mathrm{O}_{3}+11 \mathrm{CO}(\mathrm{g})+4 \mathrm{SO}_{2}(\mathrm{~g}) \rightleftharpoons 2 \mathrm{FeS}_{2}+11 \mathrm{CO}_{2}(\mathrm{~g})
$$

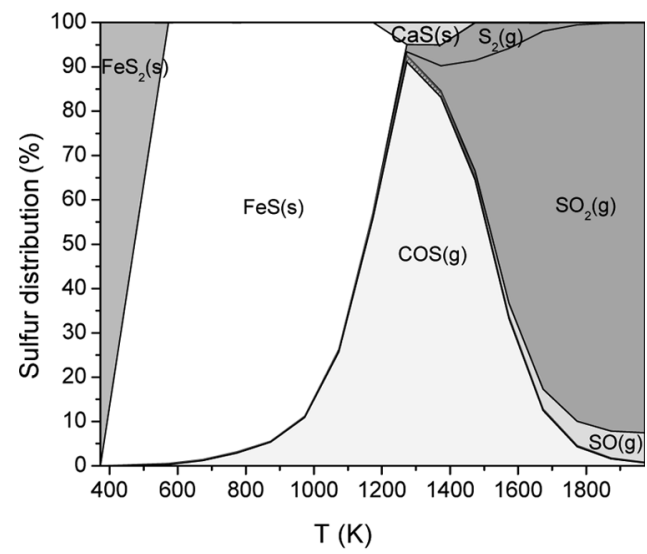

(a) $\mathrm{MR}=0.0455$

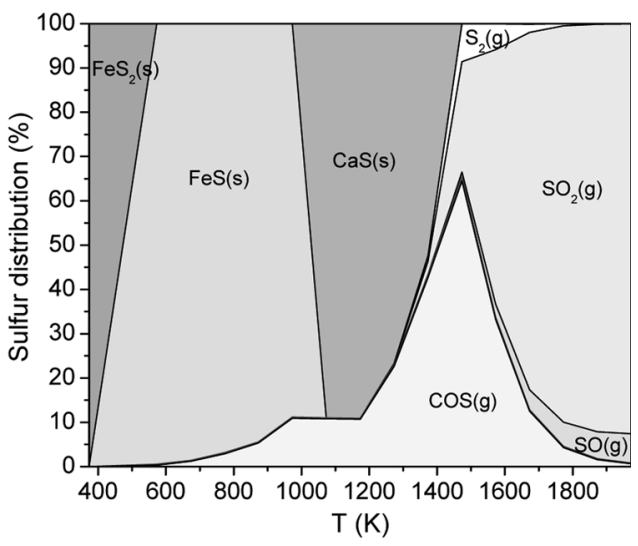

(b) $\mathrm{MR}=1$

Figure 6 The equilibrium distributions of sulfur in off-gas at reducing atmosphere $(S R=0.8)$. 


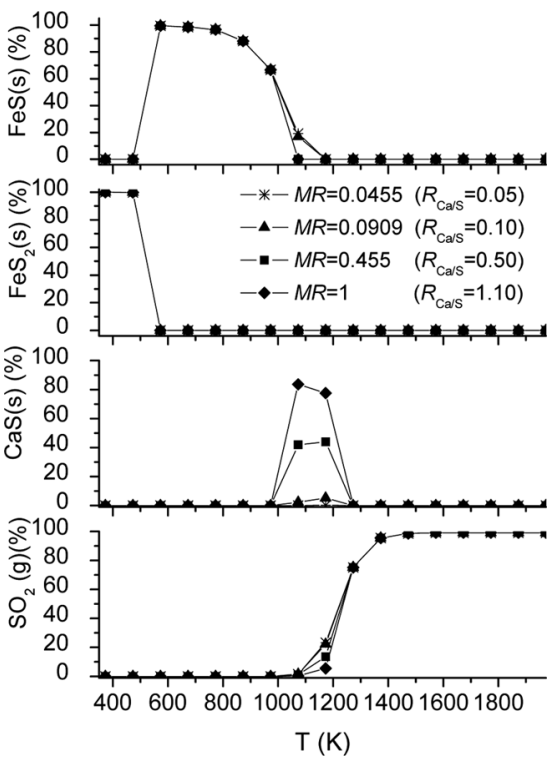

Figure 7 The influences of $M R$ and temperature on main sulfur species in off-gas at reducing atmosphere $(S R=0.8)$.

$$
\begin{gathered}
\mathrm{Fe}_{2} \mathrm{O}_{3}+7 \mathrm{CO}(\mathrm{g})+2 \mathrm{SO}_{2}(\mathrm{~g}) \rightleftharpoons 2 \mathrm{FeS}+7 \mathrm{CO}_{2}(\mathrm{~g}) \\
\mathrm{CaO}(\mathrm{s})+3 \mathrm{CO}(\mathrm{g})+\mathrm{SO}_{2}(\mathrm{~g}) \rightleftharpoons \mathrm{CaS}+3 \mathrm{CO}_{2}(\mathrm{~g})
\end{gathered}
$$

For the reversible Equations (10)-(12), the Gibbs energy $\Delta_{\mathrm{r}} G_{\mathrm{m}}^{\Theta}(T)$ and reaction equilibrium constant $K^{\Theta}(T)$ are calculated, as shown in Table 2. At $\mathrm{T}<473 \mathrm{~K}$, Equation (10) has a very small Gibbs energy $\Delta_{\mathrm{r}} G_{\mathrm{m}}^{\Theta}(T)$ and a very great reaction equilibrium constant $K^{\Theta}(T)\left(3.5 \times 10^{117} \sim 2.4 \times 10^{160}\right)$, and thus the forward reaction can autonomously happen and react. For Equation (11), at $573<\mathrm{T}<973 \mathrm{~K}$, the forward reaction can also autonomously happen and react. For Equation (12), at $1073<\mathrm{T}<1373 \mathrm{~K}, \Delta_{\mathrm{r}} G_{\mathrm{m}}^{\Theta}(T)$ gradually increases and $K^{\Theta}(T)$ drastically decreases with rising reaction temperature, which means that rising temperature is unfavorable for the desulfurization reaction (forward reaction) to proceed. Therefore, under the reducing atmosphere, the desulfurization products of dusts are iron sulfides $\left[\mathrm{FeS}_{2}(\mathrm{~s})\right.$ and $\left.\mathrm{FeS}(\mathrm{s})\right]$ at relative low temperature $(\mathrm{T}<1000 \mathrm{~K})$. When the temperature is larger than $1000 \mathrm{~K}$, calcium sulfide [CaS (s)] is formed. The increase of $M R$ is conducive to the $\mathrm{CaS}(\mathrm{s})$ formation (see Figure 6). When the temperature is higher than $1173 \mathrm{~K}$ (see Table 1), too low $K^{\Theta}(T)$ makes CaS formation drastically decrease (see Figure 7). $\mathrm{CaS}$ is an undesirable product; the decomposition of $\mathrm{CaS}$ easily occurs when moisture is high, and the direct reaction between $\mathrm{CaS}$ and $\mathrm{H}_{2} \mathrm{O}$ is

$$
\mathrm{CaS}+3 \mathrm{H}_{2} \mathrm{O} \longrightarrow \mathrm{CaO}+\mathrm{SO}_{2}+3 \mathrm{H}_{2}
$$


Table 2 The standard Gibbs energy and equilibrium constant of fluorine retention Equations (10)-(12)

\begin{tabular}{lcc}
\hline $\mathrm{T} /(\mathrm{K})$ & $\Delta_{\mathrm{r}} G_{\mathrm{m}}^{\Theta}(T) /(\mathrm{kJ})$ & $K^{\Theta}(T)$ \\
\hline & $\mathrm{Fe}_{2} \mathrm{O}_{3}+11 \mathrm{CO}(\mathrm{g})+4 \mathrm{SO}_{2}(\mathrm{~g}) \rightleftharpoons 2 \mathrm{FeS}_{2}+11 \mathrm{CO}_{2}(\mathrm{~g})$ & \\
\hline 373 & -1145.2 & $2.4 \mathrm{E}+160$ \\
473 & -1064.27 & $3.5 \mathrm{E}+117$ \\
& $\mathrm{Fe}_{2} \mathrm{O}_{3}+7 \mathrm{CO}(\mathrm{g})+2 \mathrm{SO}_{2}(\mathrm{~g}) \rightleftharpoons 2 \mathrm{FeS}+7 \mathrm{CO}_{2}(\mathrm{~g})$ & \\
573 & -569.086 & $7.62 \mathrm{E}+51$ \\
673 & -536.165 & $4.15 \mathrm{E}+41$ \\
773 & -503.276 & $1.03 \mathrm{E}+34$ \\
873 & -470.294 & $1.39 \mathrm{E}+28$ \\
973 & -437.128 & $2.94 \mathrm{E}+23$ \\
& & \\
1073 & $\mathrm{CaO}(\mathrm{s})+3 \mathrm{CO}(\mathrm{g})+\mathrm{SO}_{2}(\mathrm{~g}) \rightleftharpoons \mathrm{CaS}+3 \mathrm{CO}_{2}(\mathrm{~g})$ & $3.48 \mathrm{E}+09$ \\
1173 & -195.984 & 84528143 \\
1273 & -177.997 & 3724843 \\
1373 & -160.13 & 261391.6 \\
\hline
\end{tabular}

At $\mathrm{T}>573 \mathrm{~K}$, carbonyl sulfide gas (COS) begins to release (see Figure 5), and the formation of COS is

$$
3 \mathrm{CO}(\mathrm{g})+\mathrm{SO}_{2}(\mathrm{~g}) \rightleftharpoons \mathrm{COS}(\mathrm{g})+2 \mathrm{CO}_{2}(\mathrm{~g})
$$

Carbonyl sulfide may decompose to carbon dioxide and hydrogen sulfide if off-gas is exposed to high humidity (Protoschill-Krebsc and Kesselmeier, 1996).

$$
\mathrm{COS}(\mathrm{g})+\mathrm{H}_{2} \mathrm{O}(\mathrm{g}) \rightleftharpoons \mathrm{H}_{2} \mathrm{~S}(\mathrm{~g})+\mathrm{CO}_{2}(\mathrm{~g})
$$

When the temperature is higher than $1600 \mathrm{~K}$, the main sulfur species is $\mathrm{SO}_{2}$ with a bit of $\mathrm{SO}$ and COS, as shown in Figure 6. The main sulfides are gaseous $\mathrm{SO}_{2}, \mathrm{SO}$, and $\mathrm{COS}$ at $\mathrm{T}>1373 \mathrm{~K}$, and off-gas dusts are ineffective to desulfurization. The reaction paths of sulfur species at reducing atmosphere are summarized in Figure 8.

\section{Defluorination and Sesulfurization at Oxidizing Atmosphere}

The behaviors of sulfur in converter off-gas at oxidizing atmosphere. Figure 9 illustrates the equilibrium distributions of sulfur at oxidizing

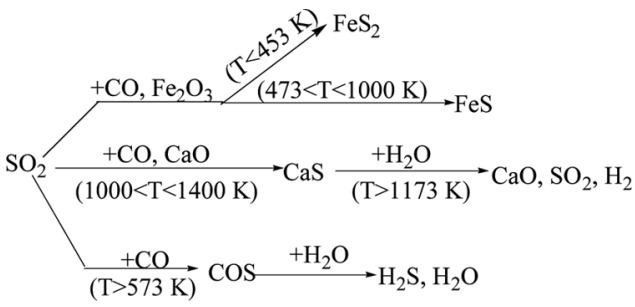

Figure 8 The reaction paths of sulfur species at reducing atmosphere. 
atmosphere at $M R=0.0455$ and $M R \geq 0.909$. The equilibrium calculation results indicate that, at $M R<0.909$, sulfide distributions at different $M R$ are similar, as shown in Figure 10. Figure 10 shows the influences of temperature and $M R$ on the distribution of sulfur species in off gas at oxidizing atmosphere. At $M R<0.909\left(R_{\mathrm{Ca} / \mathrm{S}}<1\right)$, sulfide distributions at different $M R$ are similar. Sulfides are $\mathrm{Fe}_{2}\left(\mathrm{SO}_{4}\right)_{3}(\mathrm{~s})(\mathrm{T}<773 \mathrm{~K}), \mathrm{CaSO}_{4}(\mathrm{~s})(\mathrm{T}<1500 \mathrm{~K}), \mathrm{SO}_{3}(673<\mathrm{T}<1400 \mathrm{~K})$, and $\mathrm{SO}_{2}(\mathrm{~T}>673 \mathrm{~K})$; with the increase of $M R, \mathrm{Fe}_{2}\left(\mathrm{SO}_{4}\right)_{3}(\mathrm{~s}), \mathrm{SO}_{3}$, and $\mathrm{SO}_{2}$ decrease, and $\mathrm{CaSO}_{4}(\mathrm{~s})$ increases. At $M R \geq 0.909\left(R_{\mathrm{Ca} / \mathrm{s}} \geq 1\right)$, sulfides are only $\mathrm{CaSO}_{4}(\mathrm{~s})$ and $\mathrm{SO}_{2}$. When the temperature is higher than $1473 \mathrm{~K}$, sulfide is only $\mathrm{SO}_{2}$, and off-gas dusts are ineffective to desulfurization, as shown in Figure 10.

At oxidizing atmosphere, $\mathrm{SO}_{2}$ can be oxidized to $\mathrm{SO}_{3}$

$$
\mathrm{SO}_{2}+1 / 2 \mathrm{O}_{2} \rightleftharpoons \mathrm{SO}_{3}
$$

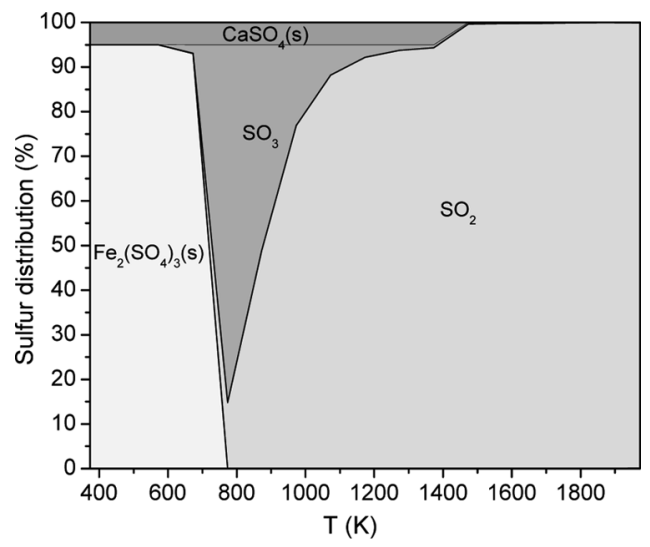

(a) $\mathrm{MR}=0.0455$

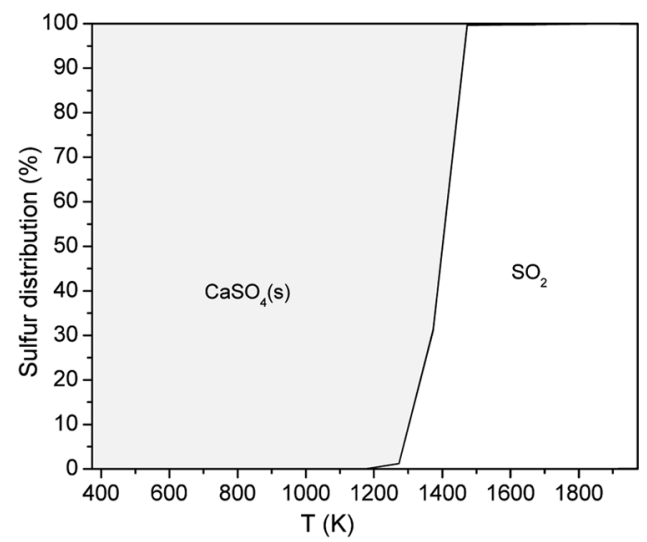

(b) $\mathrm{MR} \geq 0.909$

Figure 9 The equilibrium distributions of fluorine and sulfur at oxidizing atmosphere $(S R=1.1)$. 


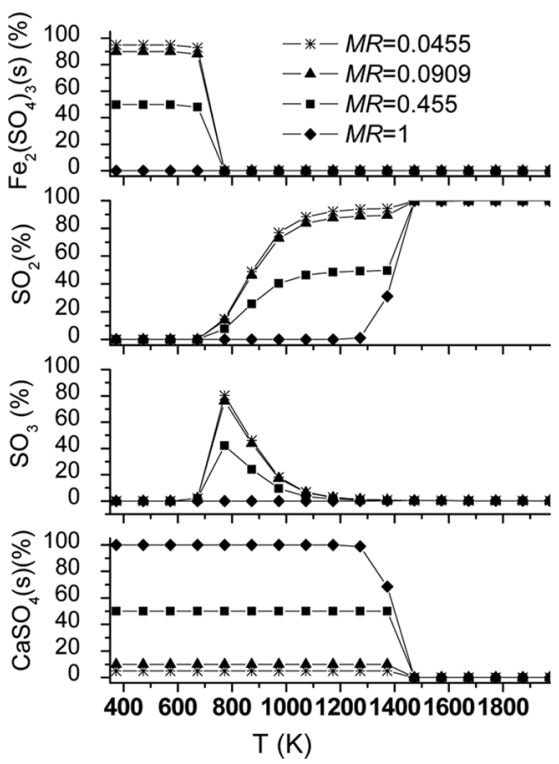

Figure 10 The influences of temperature and $M R$ on the distribution of sulfur species at oxidizing atmosphere $(S R=1.1)$.

and $\mathrm{SO}_{3}$ can react with $\mathrm{Fe}_{2} \mathrm{O}_{3}$ and $\mathrm{CaO}$ to form $\mathrm{Fe}\left(\mathrm{SO}_{4}\right)_{3}$ and $\mathrm{CaSO}_{4}$

$$
\begin{gathered}
3 \mathrm{SO}_{3}+\mathrm{Fe}_{2} \mathrm{O}_{3} \rightleftharpoons \mathrm{Fe}_{2}\left(\mathrm{SO}_{4}\right)_{3} \\
\mathrm{SO}_{3}+\mathrm{CaO} \rightleftharpoons \mathrm{CaSO}_{4}
\end{gathered}
$$

Equations (16) and (17) can combine into

$$
\mathrm{Fe}_{2} \mathrm{O}_{3}+3 \mathrm{SO}_{2}+3 / 2 \mathrm{O}_{2} \rightleftharpoons \mathrm{Fe}_{2}\left(\mathrm{SO}_{4}\right)_{3}
$$

Equations (16) and (18) can combine into

$$
\mathrm{CaO}+\mathrm{SO}_{2}(\mathrm{~g})+1 / 2 \mathrm{O}_{2}(\mathrm{~g}) \rightleftharpoons \mathrm{CaSO}_{4}
$$

At oxidizing atmosphere, at $M R<0.909$, the $\mathrm{R}_{\mathrm{Ca} / \mathrm{S}}$ is less than 1 , the amount of $\mathrm{CaO}$ is not enough to completely desulfurize, and the free $\mathrm{SO}_{2}$ can react with $\mathrm{Fe}_{2} \mathrm{O}_{3}$ to form $\mathrm{Fe}_{2}\left(\mathrm{SO}_{4}\right)_{3}$. With the increase of $M R$, the amount of $\mathrm{CaO}$ increases,

Table 3 The standard Gibbs energy and equilibrium constant of fluorine retention Equation (20)

\begin{tabular}{lcccccc}
\hline $\mathrm{T} /(\mathrm{K})$ & 373 & 473 & 573 & 673 & 773 & 873 \\
$\Delta_{\mathrm{r}} G_{\mathrm{m}}^{\Theta}(T)$ & -84.2 & -77.7 & -71.2 & -64.7 & -58.4 & -52.1 \\
$K^{\Theta}(T)$ & $5.1 \mathrm{E}+33$ & $1.9 \mathrm{E}+26$ & $7.0 \mathrm{E}+20$ & $5.2 \mathrm{E}+16$ & $3.0 \mathrm{E}+13$ & $7.5 \mathrm{E}+10$ \\
$\mathrm{~T} /(\mathrm{K})$ & 973 & 1073 & 1173 & 1273 & 1373 & 1473 \\
$\Delta_{\mathrm{r}} G_{\mathrm{m}}^{\Theta}(T)$ & -45.8 & -39.7 & -33.6 & -27.6 & -21.7 & -15.9 \\
$K^{\Theta}(T)$ & $5.48 \mathrm{E}+08$ & $9.1 \mathrm{E}+06$ & $2.8 \mathrm{E}+05$ & $1.5 \mathrm{E}+04$ & $1.2 \mathrm{E}+03$ & $1.3 \mathrm{E}+02$ \\
\hline
\end{tabular}




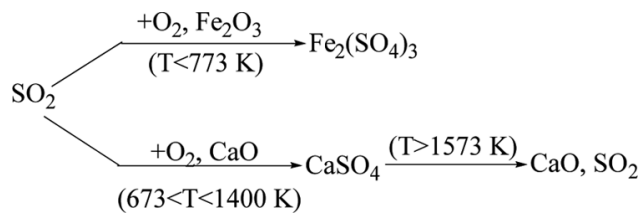

Figure 11 The reaction paths of sulfur species at oxidizing atmosphere.

the free $\mathrm{SO}_{2}$ decreases after $\mathrm{CaO}$ desulfurization, and then the desulfurization production $\left[\mathrm{Fe}_{2}\left(\mathrm{SO}_{4}\right)_{3}\right]$ of $\mathrm{Fe}_{2} \mathrm{O}_{3}$ decreases (see Figure 10). Figure 10 indicates that $\mathrm{Fe}_{2}\left(\mathrm{SO}_{4}\right)_{3}$ drastically decreases at $\mathrm{T}>673 \mathrm{~K}$, and this is because $\mathrm{Fe}_{2}\left(\mathrm{SO}_{4}\right)_{3}$ can be decomposed. Experiments found that $\mathrm{Fe}_{2}\left(\mathrm{SO}_{4}\right)_{3}$ could be decomposed when temperature was $800 \mathrm{~K}$ (Zboril et al., 2003). Therefore, the results of equilibrium calculation and the experiment are very agreeable.

For the reversible reaction, Equation (20), Gibbs energy $\Delta_{\mathrm{r}} G_{\mathrm{m}}^{\Theta}(T)$ and reaction equilibrium constant $K^{\Theta}(T)$ can be calculated, as shown in Table 3 . At T $>1273 \mathrm{~K}$, $\Delta_{\mathrm{r}} G_{\mathrm{m}}^{\Theta}(T)$ gradually increases and $K^{\Theta}(T)$ drastically decreases with rising reaction

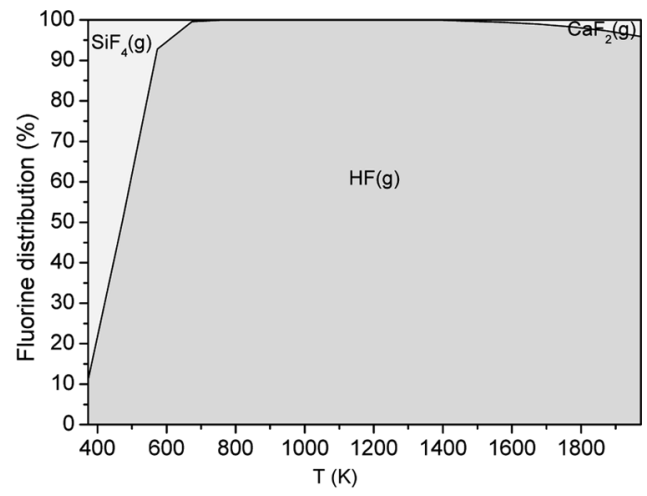

(a) $\mathrm{MR}<0.909$

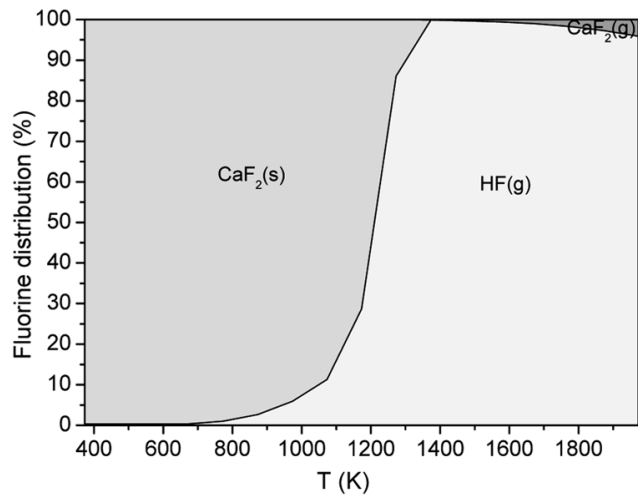

(b) $M R \geq 1$

Figure 12 The equilibrium distributions of fluorine and sulfur at oxidizing atmosphere $(S R=1.1)$. 
temperature, and this means that rising temperature is unfavorable to the procession of the desulfurization reaction (forward reaction). At $\mathrm{T}>1573 \mathrm{~K}$, the backward reaction occurs, and $\mathrm{CaSO}_{4}$ is decomposed into $\mathrm{SO}_{2}$ and $\mathrm{CaO}$. Therefore, at $\mathrm{T}>1573 \mathrm{~K}$, off-gas dust is ineffective to desulfurization. In comparison with Equation (3), the equilibrium constant of Equation (18) is larger than that of Equation (3) at $\mathrm{T}<873 \mathrm{~K}$ (see Tables 1 and 3), thus desulfurization reaction first occurs when $\mathrm{O}_{2}$ is sufficient at oxidizing atmosphere. At $M R<0.909$, the ratio of $\mathrm{Ca}: \mathrm{S}$ is less than 1 , $\mathrm{CaO}$ reacts with $\mathrm{SO}_{3}$ to form $\mathrm{CaSO}_{4}$, and $\mathrm{CaSO}_{4}$ increases with the increase of $M R$. The reaction paths of the sulfur species at oxidizing atmosphere are summarized in Figure 11.

The behaviors of fluorine in converter off-gas at oxidizing atmosphere. Figure 12 illustrates the equilibrium distributions of fluorides at oxidizing atmosphere at $M R<0.909$ and at $M R \geq 1$. At $M R<0.909$, fluorides are $\mathrm{SiF}_{4}(\mathrm{~g})(\mathrm{T}<673 \mathrm{~K}), \mathrm{CaF}_{2}(\mathrm{~g})(\mathrm{T}>1473 \mathrm{~K})$, and $\mathrm{HF}$. At $M R \geq 1$, fluorides are $\mathrm{CaF}_{2}(\mathrm{~s})(\mathrm{T}<1373 \mathrm{~K}), \mathrm{CaF}_{2}(\mathrm{~g})(\mathrm{T}>1473 \mathrm{~K})$, and $\mathrm{HF}(\mathrm{g})$.

Figure 13 shows the influence of temperature and $M R$ on the distributions of fluorine species in off-gas at oxidizing atmosphere. At $M R<0.909$, the distribution variations of fluorides with temperature are the same. The main fluorides are only gaseous $\mathrm{SiF}_{4}(\mathrm{~T}<673 \mathrm{~K})$ and $\mathrm{HF}$, and $\mathrm{CaO}$ does not defluorinate. At $M R>0.909$, fluorides are $\mathrm{HF}, \mathrm{CaF}_{2}(\mathrm{~g})$, and $\mathrm{CaF}_{2}(\mathrm{~s})$, and $\mathrm{CaF} 2(\mathrm{~s})$ content increases with $M R$ at $\mathrm{T}<1400 \mathrm{~K}$. At oxidizing atmosphere, defluorination and desulfurization by dusts are completely effective at $M R \geq 1$ and $\mathrm{T}<1100 \mathrm{~K}$.

$\mathrm{CaO}$ in off-gas dusts is sorbent for both $\mathrm{SO}_{2}$ and $\mathrm{HF}$. For a certain amount of desulfurization and defluorination sorbent $(\mathrm{CaO})$, the desulfurization Equation (18)

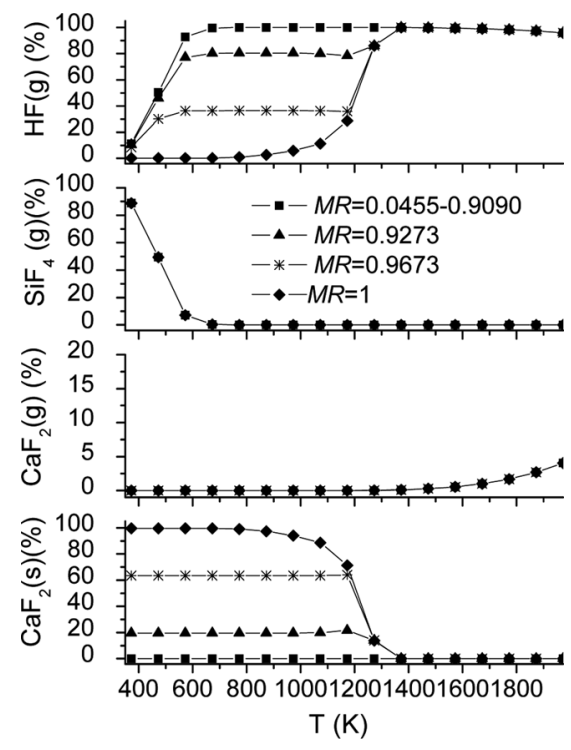

Figure 13 The influences of temperature and MR on the distributions of fluorine species in off-gas at oxidizing atmosphere $(S R=1.1)$. 
Table 4 Sulfur and fluorine species in off-gas under different combustion conditions

\begin{tabular}{|c|c|c|c|}
\hline SR & MR & Sulfur species & Fluorine species \\
\hline \multirow[t]{2}{*}{0.8} & $\geq 0.0909$ & $\begin{array}{l}\mathrm{CaF}_{2}(\mathrm{~s})(\mathrm{T}<1400 \mathrm{~K}) ; \mathrm{HF} \\
\quad(\mathrm{T}>1400 \mathrm{~K})\end{array}$ & $\begin{array}{l}\mathrm{FeS}_{2} \text { (s) }(\mathrm{T}<473 \mathrm{~K}) ; \mathrm{FeS}(\mathrm{s})(473<\mathrm{T}<1000 \mathrm{~K}) \\
\quad \mathrm{CaS}(\mathrm{s})(1000<\mathrm{T}<1400 \mathrm{~K})\end{array}$ \\
\hline & 0.0455 & $\begin{array}{l}\mathrm{SiF}_{4}(\mathrm{~T}<600 \mathrm{~K}) ; \mathrm{CaF}_{2}(\mathrm{~s}) \\
\quad(\mathrm{T}<1400 \mathrm{~K}) ; \mathrm{HF}(\mathrm{T}>400 \mathrm{~K})\end{array}$ & \\
\hline \multirow[t]{2}{*}{1.1} & $\geq 0.909$ & $\begin{array}{l}\mathrm{CaF}_{2}(\mathrm{~s})(\mathrm{T}<1373 \mathrm{~K}), \mathrm{CaF}_{2}(\mathrm{~g}) \\
(\mathrm{T}>1473 \mathrm{~K}) \text { and } \mathrm{HF}(\mathrm{g})\end{array}$ & $\mathrm{CaSO}_{4}(\mathrm{~s})(\mathrm{T}<1500 \mathrm{~K})$ and $\mathrm{SO}_{2}(\mathrm{~T}>1300 \mathrm{~K})$ \\
\hline & $<0.909$ & $\begin{array}{l}\mathrm{SiF}_{4}(\mathrm{~g})(\mathrm{T}<673 \mathrm{~K}), \mathrm{CaF}_{2}(\mathrm{~g}) \\
\quad(\mathrm{T}>1473 \mathrm{~K}) \text { and } \mathrm{HF}\end{array}$ & $\begin{array}{l}\mathrm{Fe}_{2}\left(\mathrm{SO}_{4}\right)_{3}(\mathrm{~s})(\mathrm{T}<773 \mathrm{~K}), \mathrm{CaSO}_{4}(\mathrm{~s})(\mathrm{T}<1500 \mathrm{~K}), \mathrm{SO}_{3} \\
\quad(673<\mathrm{T}<1400 \mathrm{~K}) \text { and } \mathrm{SO}_{2}(\mathrm{~T}>673 \mathrm{~K})\end{array}$ \\
\hline
\end{tabular}

and defluorination Equation (3) are competition reactions. The equilibrium constant of Equation (18) is larger than that of Equation (3) at $\mathrm{T}<873 \mathrm{~K}$ (see Tables 1 and 3) at oxidizing atmosphere, then the desulfurization reaction first occurs. At $M R<0.909$, although $\mathrm{R}_{\mathrm{CaO} / \mathrm{HF}}$ may be larger than $0.5, \mathrm{R}_{\mathrm{Ca} / \mathrm{s}}$ is less than 1 , the amount of $\mathrm{CaO}$ is not enough to completely desulfurize, and there is not $\mathrm{CaO}$ left for defluorination. Therefore, at $M R<0.909$, $\mathrm{HF}$ only can react with $\mathrm{SiO}_{2}$ in off-gas dusts to form gaseous $\mathrm{SiF}_{4}$ at low temperature $(\mathrm{T}<573 \mathrm{~K})$, and a large amount of $\mathrm{HF}$ releases at high temperature at $0.909<M R<1$. When $\mathrm{R}_{\mathrm{Ca} / \mathrm{S}}$ is larger than 1 , the residual $\mathrm{CaO}$ after desulfurization can react with $\mathrm{HF}$ to form $\mathrm{CaF}_{2}(\mathrm{~s})$, the residual $\mathrm{CaO}$ increases with the increase of $M R$, and then the defluorination production $\left[\mathrm{CaF}_{2}(\mathrm{~s})\right]$ increases with the increase of $M R$ at $\mathrm{T}<1400 \mathrm{~K}$. At $M R \geq 1$, the amount of $\mathrm{CaO}$ is enough to desulfurize and defluorinate, thus the distribution variations of fluorides with temperature are the same, as shown in Figure 13.

As known from the discussion above, the results of chemical equilibrium calculations of fluorine and sulfur behaviors are affected by converter off-gas dusts, so at high temperature $(\mathrm{T}>1500 \mathrm{~K})$, the desulfurization and defluorination by dusts are difficult. Under oxidizing atmosphere and reasonable temperature conditions (i.e., $M R \geq 1$ and $\mathrm{T}<1100 \mathrm{~K}$ ), defluorination and desulfurization by dusts are completely effective during converter off-gas combustion.

\section{CONCLUSION}

The desulfurization and defluorination of converter off-gas by dusts were estimated using chemical equilibrium, and the influences of temperature and atmosphere of converter off-gas on desulfurization and defluorination are investigated. The results indicate that the behaviors of fluorine and sulfur during off-gas combustion are very different at reducing and oxidizing atmospheres, as shown in Table 4.

At reducing atmosphere, the main fluorides in off-gas are $\mathrm{SiF}_{4}(\mathrm{~g}), \mathrm{CaF}_{2}(\mathrm{~s}), \mathrm{HF}$, and $\mathrm{CaF}_{2}(\mathrm{~g})$, and the main sulfides are $\mathrm{FeS}_{2}(\mathrm{~s}), \mathrm{FeS}(\mathrm{s}), \mathrm{COS}(\mathrm{g}), \mathrm{SO}_{2}(\mathrm{~g})$, and $\mathrm{S}_{2}(\mathrm{~g})$. Also, $\mathrm{CaO}$ can effectively defluorinate at $\mathrm{T}<1000 \mathrm{~K}$. At oxidizing atmosphere, the main fluorides are $\mathrm{SiF}_{4}(\mathrm{~g}), \mathrm{HF}$, and $\mathrm{CaF}_{2}(\mathrm{~g})$; the main sulfides are $\mathrm{Fe}_{2}\left(\mathrm{SO}_{4}\right)_{3}(\mathrm{~s})$, $\mathrm{CaSO}_{4}(\mathrm{~s}), \mathrm{SO}_{2}(\mathrm{~g})$, and $\mathrm{SO}_{3}(\mathrm{~g})$; and defluorination and desulfurization by $\mathrm{CaO}$ are completely effective at $M R \geq 1$ and $\mathrm{T}<1100 \mathrm{~K}$. For the converter steelmaking business, under oxidizing atmosphere and reasonable temperature conditions (i.e., 
$M R \geq 1$ and $\mathrm{T}<1100 \mathrm{~K}$ ), defluorination and desulfurization by dusts are completely effective during converter off-gas combustion.

\section{ACKNOWLEDGMENTS}

Financial supports by the National Natural Science Foundation of China (No. 50976123) and the Knowledge Innovation Program of the Chinese Academy of Sciences (No. KGCX2-YW-321) are acknowledged.

\section{REFERENCES}

Aleksashin, A.L., Schnaltzger, I., and Hollias, G. 2007. Creation and growth of oxygen-converter steelmaking. Metallurgist, 51, 1573.

Alfonso, F.I., and Sung, C.J. 2006. Optimization of Jet-A fuel reforming for aerospace applications. Int. J. Hydrogen Energy, 31, 1066.

Byer, S.G., Wong, C., Yang, R.T., Reinhardt, J.R. 1983. Kinetics of the reaction between hydrofluoric acid and calcium oxide for fluoride emission control. Environ. Sci. Technol., $17,84$.

Cheng, J., Zhou, J.H., Liu, J.Z., and Zhou, Z.J. 2003. Sulfur removal at high temperature during coal combustion in furnaces: A review. Prog. Energy Combust. Sci., 29, 381.

Dehne, G. 1987. Relationship between fluorine emission during firing of ceramic products and the firing temperature and composition of raw material. Appl. Clay Sci., 2, 1.

Feng, J.H. 2005. Steelmaking Design Principles, Chemical Industry Press, Beijing.

Gonzalez, I.P., Aparicio, E., and Galan, B.F. 2002. A proposal for reducing F and $\mathrm{Cl}$ emission in the brick industry using new formulations. Appl. Clay Sci., 22, 1.

Guo, Z.C., Yu, X.P., Wang, R.Y., and Xie, Y.S. 1999. Research on the utilization of EAF dust as sulfur absorbent. Coal Chemistry Industry, 3, 33.

McBride, B.J., Zehe, M.J., and Gordon, S. 2002. NASA Glenn Coefficients for Calculating Thermodynamic Properties of Individual Species. NASA report TP-2002-211556, http://gltrs.grc.nasa.gov/cgi-bin/GLTRS/browse.pl?2002/TP-2002-211556.html

Mjaanes, H.P., Chan. L., and Mastorakos, E. 2005. Hydrogen production from rich combustion in porous media. Int. J. Hydrogen Energy, 30, 579.

Protoschill-Krebsc, G., and Kesselmeier, W.J. 1996. Consumption of carbonyl sulphide (COS) by higher plant carbonic anhydrase (CA). Atmos. Environ., 30, 3151.

Qi, Q.J., Liu, J.Z., Cao, X.Y., Zhou, J.H., Zhang, S.X., and Cen, K.F. 2002. Stability of $\mathrm{CaF}_{2}$ at high temperature. Chin. J. Environ. Sci., 23, 111.

Qi, Q.J., Lin, Z.Y., Liu, J.Z., Wu, X., Zhou, J.H., and Cen, K.F. 2008a. Experimental research on combustion fluorine retention using calcium-based sorbets during coal combustion (I). J. Coal Sci. Eng., 14, 303.

Qi, Q.J., Ma, X.Y., Liu, J.Z., Wu, X., Zhou, J.H., and Cen, K.F. 2008b. Experimental research on combustion fluorine retention using calcium-based sorbets during coal combustion (II). J. Coal Sci. Eng., 14, 667.

Sanford, G., and Bonnie, J.M. 1994. Computer program for calculation of complex chemical equilibrium compositions and applications. NASA Reference Publication. National Aeronautics and Space Administration, Washington, DC.

Vican, J., Gajdeczko, B.F., Dryer, F.L., Milius, D.L., Aksay, I.A., and Yetter, R.A. 2002. Development of a microreactor as a thermal source for microelectromechanical systems power generation. Proc. Combust. Inst., 29, 909. 
Wu, W.H., Xie, Z.M., Xu, J.M., and Liu, C. 2001. Characteristics of fluoride emission from five clay minerals as affected by temperature, heating time and addition of calcium compounds. Journal of Zhejiang University-Science A, 2, 284.

Xie, Z.M., Wu, W.H., and Xu, J.M. 2003. Study on fluoride emission from soils at high temperature related to brick-making process. Chemosphere, 50, 763.

Ye, S.F., Yang, X.M., Xie, Y.S., and Guo, Z.C. 2000. Study on the sulfur capacity of metallurgical dusts. China Environmental Science, 20, 457.

Zboril, R., Mashlan, M., Papaefthymiou, V., and Hadjipanayis, G. 2003. Cubic B-Fe $\mathrm{O}_{3}$ as the product of the thermal decomposition of $\mathrm{Fe}_{2}\left(\mathrm{SO}_{4}\right)_{3}$ : Demonstration of $\mathrm{Fe}_{2} \mathrm{O}_{3}$ polymorphism. J. Radioanal. Nucl. Chem., 255, 413.

Zhao, R.F., Ye, S.F., and Xie, Y.S. 2004. Estimation of desulfurization abilities of metallurgical dust at different atmospheres. Energy Sources Part A, 26, 135. 